\title{
LORICARIA PLECOSTOMUS.
}

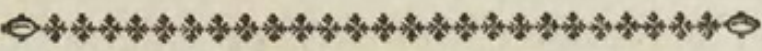

\section{CHARACTER GENERICUS.}

Corpus loricatum.

Os fubtus.

$$
\text { Bloch. ichth. 11. p. } 55 \text {. }
$$

CHARACTER SPECIFICUS, Eंc。

LORICARIA flava, fufco maculata, cauda friis plurimis tranfverfis fufcis, dorfo dipterygio.

LORICARIA PLECOSTOMUS. L. pinnis dorfi duabus.

$$
\text { Lin. Syf. Nat. p. } 508 .
$$

ACCIPENSER Indicus. A ore cirris duobus.

$$
\text { Lin. muf. Ad. Frid. p. 55. t. 28. f. } 4 .
$$

LORICARIA PLECOSTOMUS.

$$
\text { Bloch. 11. p. 57. t. } 374 \text {. }
$$

Genus Loricaria paucas continet fpecies, quarum illa in tabula depicta rivos incolit Americanos, in Brafilia præcipue reperta, longitudine, ut plurimum, pedali. 




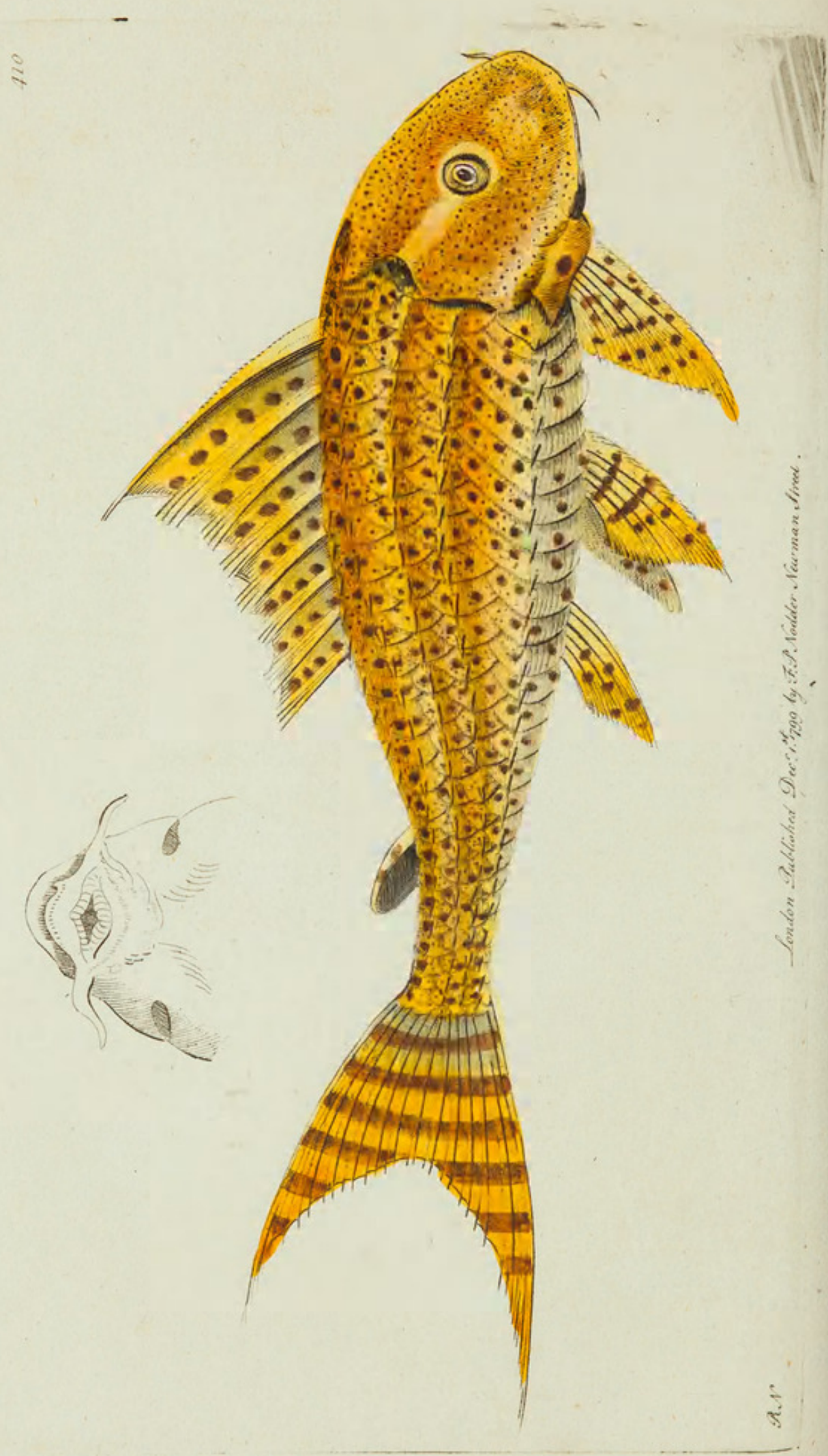


THE

\section{YELLOW LORICARIA.}

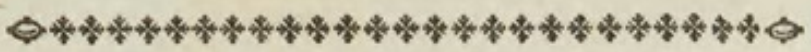

GENERIC CHARACTER.

Body mailed.

Mouth fituated underneath.

\section{SPECIFIC CHARACTER, छेC.}

YELLOW LORICARIA, fpotted with brown, with two dorfal fins, and tail marked with feveral brown tranfverfe ftripes.

The genus Loricaria contains but very few fpecies, of which that reprefented on the prefent plate is a native of the American rivers, and is principally found in Brafil. Its general length is about a foot. 


\section{$2 \mathrm{BHL}$ Biodiversity Heritage Library}

Shaw, George. 1799. "The Yellow Loricaria, Loricaria plecostomus [PI. 410]." The Naturalist's Miscellany 11(CXXIV), https://doi.org/10.5962/p.310857.

View This Item Online: https://www.biodiversitylibrary.org/item/276496

DOI: https://doi.org/10.5962/p.310857

Permalink: https://www.biodiversitylibrary.org/partpdf/310857

\section{Holding Institution}

Museums Victoria

\section{Sponsored by}

Atlas of Living Australia

\section{Copyright \& Reuse}

Copyright Status: Public domain. The BHL considers that this work is no longer under copyright protection.

This document was created from content at the Biodiversity Heritage Library, the world's largest open access digital library for biodiversity literature and archives. Visit BHL at https://www.biodiversitylibrary.org. 